\title{
CORROSION OF THE GAS PIPELINES OF THE FIELD MEDVEZHIYE IN THE DIFFERENT LANDSCAPE TYPES
}

\author{
Michael A.Velikotskij ${ }^{1 *}$, Vadim P. Marakhtanov ${ }^{1}$ \\ 'Faculty of Geography, Lomonosov Moscow State University, Leninskie Gory, 119991 Moscow, Russia \\ *Corresponding author: velikotskij@mail.ru
}

Received: July $2^{\text {th }}, 2019$ / Accepted: May 10 $10^{\text {th }}, 2020$ / Published: October 1st 2020

https://DOI-10.24057/2071-9388-2019-80

ABSTRACT. A forecast of the corrosion activity within different landscapes of the cryolithozone is poorly studied previously. This study represent a close correlation between the proportion of corroded sections of the gas pipeline route of the gas field Medvezhye (the North of Western Siberia, Russia) and the deviation of the redox potential of soils ( $\triangle$ Eh) depending on the specific landscape types (tract groups). Our study revealed that the maximum value of the standard deviation of the redox potential $(\Delta E$ E) predetermines the maximum currents of the differential pairs aeration of soils that activate electrochemical corrosion processes in pipelines. The value of $\Delta$ Eh is proposed to use as the main indicator of the activity of corrosion of the landscape types in the permafrost region.

KEY WORDS: cryolithozone, permafrost, landscapes, steel pipelines, corrosion, redox potential, tundra, forest-tundra

CITATION: Michael A.Velikotskij, Vadim P. Marakhtanov (2020). Corrosion Of The Gas Pipelines Of The Field Medvezhiye In The Different Landscape Types. Geography, Environment, Sustainability.

https://DOl-10.24057/2071-9388-2019-80

ACKNOWLEDGEMENTS: Work performed under state budget themes of «Geoecological analysis and forecast of the dynamics of the cryolithozone of the Russian Arctic», number TSITIS AAAA-A16-116032810055-0.

Conflict of interests: The authors reported no potential conflict of interest.

\section{INTRODUCTION}

The question of the degree of the activity of corrosion of cryolithozone soils for steel pipelines is still debatable. In practice various indicators are used to assess the degree of the activity of corrosion: soil grain size distribution, humidity, ion extract composition of water extract, soil electrical resistance $(\rho)$, acidity index $(\mathrm{pH})$, redox potential
(Eh), etc. (State standard GOST 9.602-89.1989) However, in cryolithozone not all of these indicators have the same significance for assessing the corrosivity of soils.

All existing assessment of the soil corrosiveness in relation to steel pipelines have been based on the results of experiments in the framework of the «point» models in the laboratory conditions, while the pipes are essentially macro-systems. Therefore the established patterns require

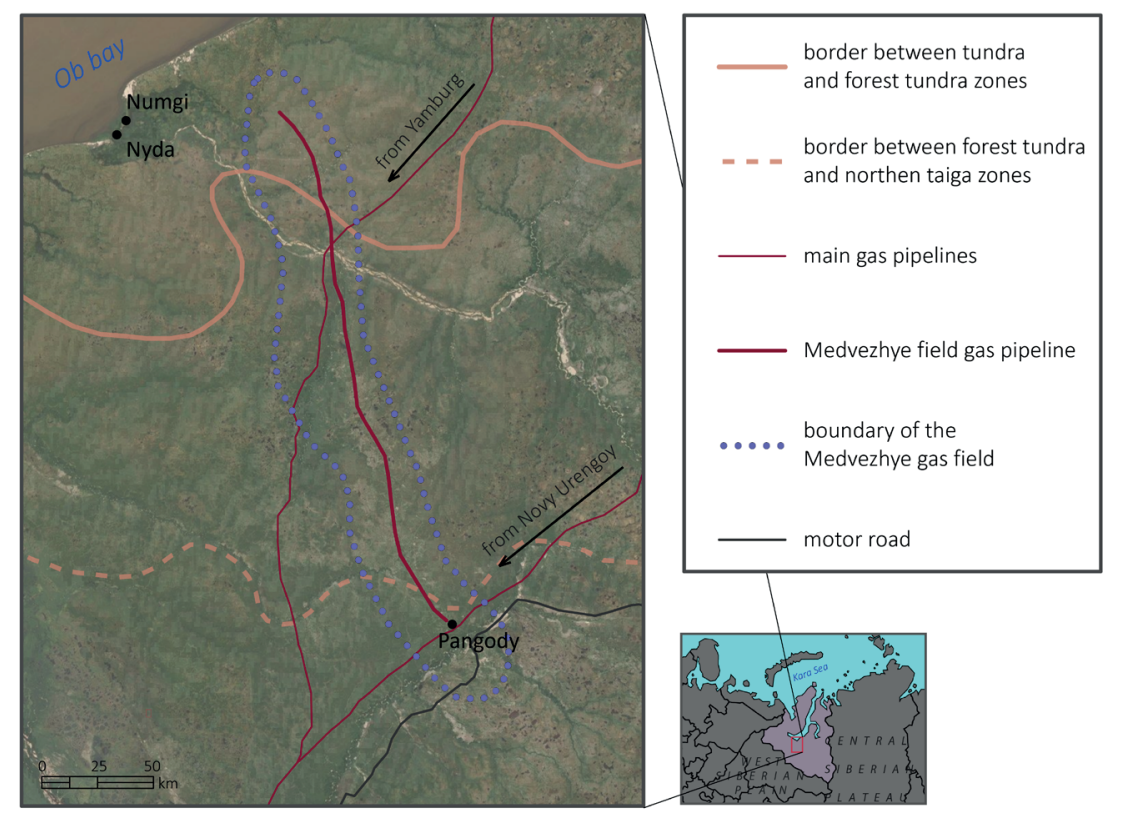

Fig. 1. The gas field Medvezhye 
adjustment in the light of this circumstance. The authors have performed all relevant studies at the specific object the gas pipelines of the interfield collector of the gas field Medvezhye in the north of the Tyumen Region (Fig. 1).

In a number of studies on the influence of natural factors on the corrosion of steel gas pipelines (Velikotskij, Egurtsov 2008; Velikotskij 2010; Velikotskij 2018) environmental conditions were assessed at the level of geographical zones, the leading role of climate and humidity in the formation of soil corrosiveness was noted. In studies on the interfield collector, it became possible to take into account the influence of natural factors at the level of landscape formations in the rank of natural tracts typical for the entire territory of the permafrost zone of Western Siberia on the activity of corrosion (Velikotskij 2015; Velikotskj 2016; Velikotskj, Marakhtanov 2012, 2017; Velikotskij, Marakhtanov 2012).

The gas field Medvezhye is an ideal object for such explorations. It is located within three geographical zones: forest (north-taiga subzone), forest-tundra and tundra (Fig. $1)$, and the results can be considered representative of the entire territory of the north of Western Siberia occupied by oil and gas fields (Marakhtanov, Velikotskij, Chigir 2011; Marakhtanov, Velikotskij, Egurtsov 2012). The work was carried out on gas pipelines of large-diameter (1420 mm) as a part of the inter field collector with a total length of $190 \mathrm{~km}$ that was commissioned from 1973 to 1978. Over 30 years of operation and deboning here destroyed 13-14\% of pipeline sections (Marakhtanov and Velikotskij 2009), and made it possible to access the surface of the pipeline affected by corrosion (Fig. 2).

\section{RESEARCH METHODS}

At the first stage of research (2000-2006) the landscape zoning of the territory was carried out with the identification of different types of landforms (Table 1).

Identifying the landforms, we relied mostly on the classic works of the geocryology department of Russian Research Institute of Hydrogeology and Engineering Geology (Landscapes of the permafrost zone of the West Siberian gas province 1983).

The landforms are combined into 4 different groups that can be conventionally designated as the landscape type
- forest, tundra, swamp, peatland. Landscape types differ significantly among themselves in permafrost conditions. The temperature of the permafrost varies from $0^{\circ} \mathrm{C}$ in the forest to $-5^{\circ} \mathrm{C}$ in the tundra and on peatlands. In the forest, seasonal thawing of soil can reach $2-3 \mathrm{~m}$ and within peatlands it usually does not exceed $0.5 \mathrm{~m}$. Landscape types also differ very much from each other in terms of watering, microrelief features, lithological and physicochemical characteristics that predetermine their various activity of corrosion. (Kolotovsky A.N., Egurtsov S.A., Skrynnik T.V., Danilov O.A., Korolev A.E., Velikotskij M.A. 2015; Marakhtanov, Velikotskij 2015).

The map of landforms of the territory (about $100 \mathrm{~km}$ ) intersected by two lines of the gas pipelines has been compiled based on the interpretation of aerial and satellite photographs. The fragment of the map is shown in Figure 3.

In addition to the boundaries of tracts the map shows the points of soil sampling for laboratory tests as well as the lines of two gas pipelines of the interfield collector with pickets and a display of their technical condition. In places without deboning the condition is determined by the combination of three structural elements of the gas pipeline - insulation coating, pipeline metal and spatial position of the pipe (in accordance with the table in Fig. 3).

At the second stage of research (2007-2010) during the visual inspection of gas pipelines with a special device (Fig. 4) the depth of corrosion pits in the metal was measured within different landscape types.

For the assessment of corrosivity soil samples were taken within all landscape types. In the soil-ecological laboratory of the Institute of Physicochemical and Biological Problems of Soil Science of the Russian Academy of Sciences in Pushchino, Moscow region, physicomechanical (particle size distribution, humidity), chemical (ionic composition of the aqueous extract ${ }^{++}, \mathrm{K}^{+}, \mathrm{Na}^{+}, \mathrm{Mg}^{++}, \mathrm{CO}_{3--} \mathrm{SO}_{4-,} \mathrm{Cl}$, $C_{\text {org }}$ ), physicochemical $(E h, p H, r H)$ and physical (electrical conductivity $\rho_{\text {, }}$ ) properties of soils were determined.

Among these indicators we paid special attention to the value of the redox potential Eh. At the first stages of the study of corrosion activity of soil it was believed (Mingalev 1978; Strizhevsky 1986) that high Eh values indicate low soil corrosion activity, and values close to zero and negative values indicate high corrosion activity. As we know, metal corrosion in its physicochemical nature is an oxidation-

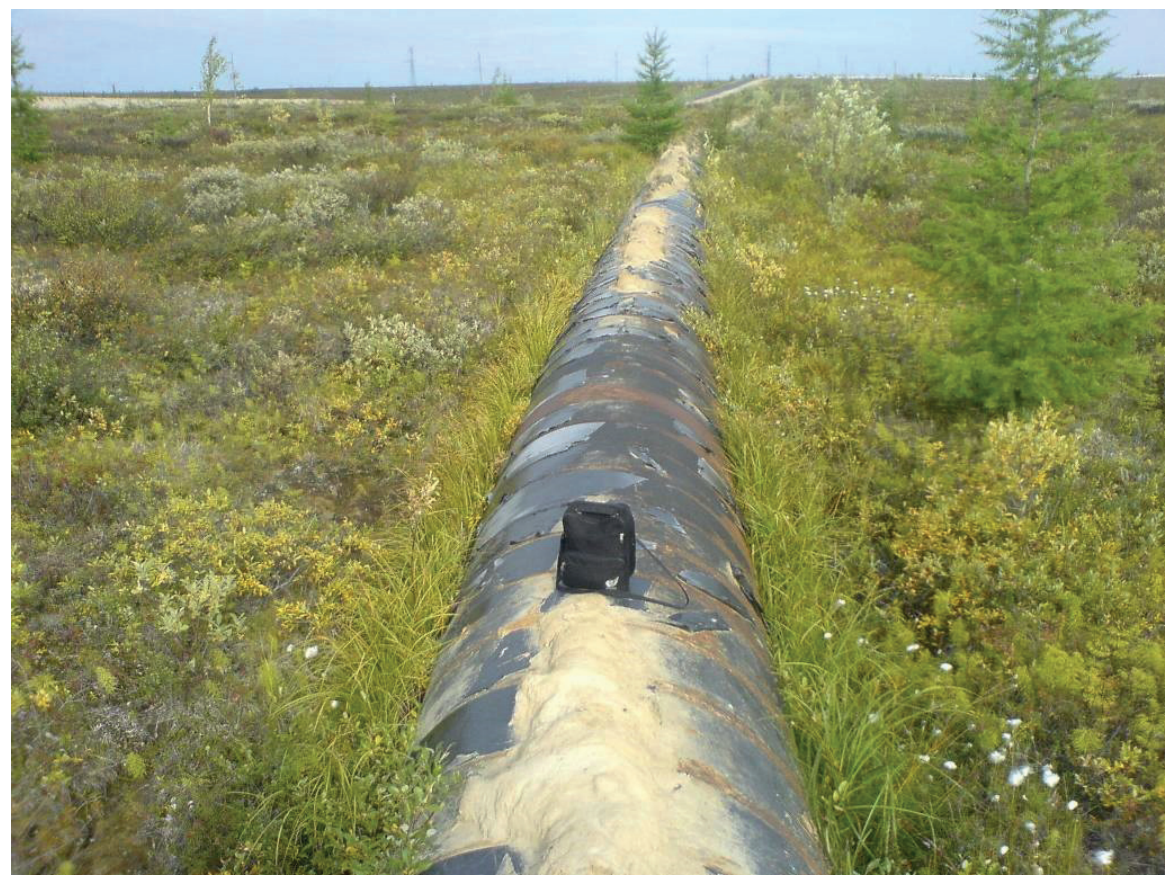

Fig. 2. The pipeline section without deboning 
Table 1. The landforms of gas fields in the North of Western Siberia (Velikotsky, 2004)

\begin{tabular}{|c|c|}
\hline Numbers of landforms & Types of landforms and of landscapes \\
\hline & Forest \\
\hline 1 & Closed spruce-birch-larch forests of floodplains \\
\hline 2 & Birch-larch sparous forests of the rivers \\
\hline 3 & Birch-larch spotted-medallion lichen meadows on slopes and hills, sometimes residual polygons are observed \\
\hline 4 & Larch speckled medallion openings on weakly drained basins \\
\hline \multirow[t]{2}{*}{5} & Larch openings on the polygonal surfaces of the slopes (polygonal sparous forests, openlands, light forests) \\
\hline & Tundra \\
\hline 6 & Shrub-moss-lichen, small-topped, with tundra-medallions on well-drained hills \\
\hline 7 & Shrub-moss-lichen tundra on flat, relatively well-drained interfluve surfaces \\
\hline 8 & Small-tuberous shrub-moss-lichen tundra on concave weakly drained interfluve surfaces \\
\hline 9 & Shrub-moss-lichen, polygonal tundra with medallions on flat and inclined slightly drained interfluve surfaces \\
\hline 10 & Grass-shrub-mossy, hummocky on flat, slightly drained surfaces of floodplains and low river terraces \\
\hline \multirow[t]{2}{*}{11} & Bushy (on the sides of Hasyree, rear terraces, logs and narrow river valleys, at the foot of the slopes) \\
\hline & Swamp \\
\hline 12 & Grass-moss watered (swampy) flat swamps \\
\hline 13 & $\begin{array}{c}\text { Complex swamps (flat, hummocky sedge-sphagnum swamps in combination with shrub-grass-lichen tundra and } \\
\text { fragments of peatlands) }\end{array}$ \\
\hline \multirow[t]{2}{*}{14} & Bedside swamps \\
\hline & Peatland \\
\hline 15 & Small peat bogs with grass-moss hollows \\
\hline 16 & Low flat peatlands with grass-moss hollows \\
\hline 17 & Flat-faced, moor-covered peatlands (up to $4 \mathrm{~m}$ thick) with grass-moss hollows \\
\hline 18 & Polygonal peatlands with veined ice \\
\hline 19 & Convex-hilly peatlands \\
\hline
\end{tabular}

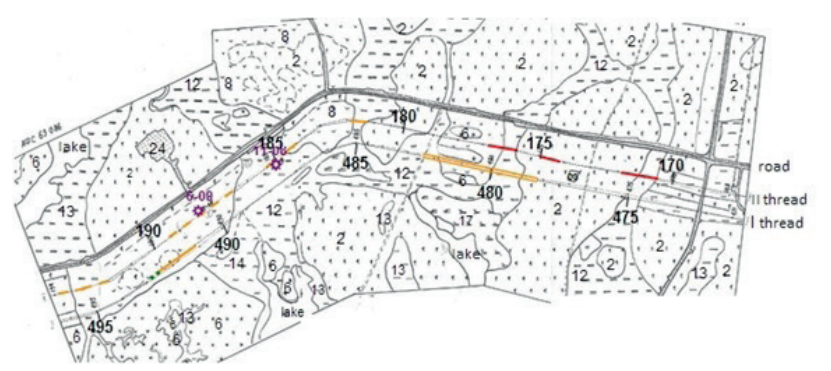

7 the numbers of the landforms (according to table 1)

motor road

16. soil sampling point and number

TECHNICAL CONDITION OF THE PIPELINE

sections of the pipeline with well-preserved embankment

Characteristics of defects of technical condition in the areas

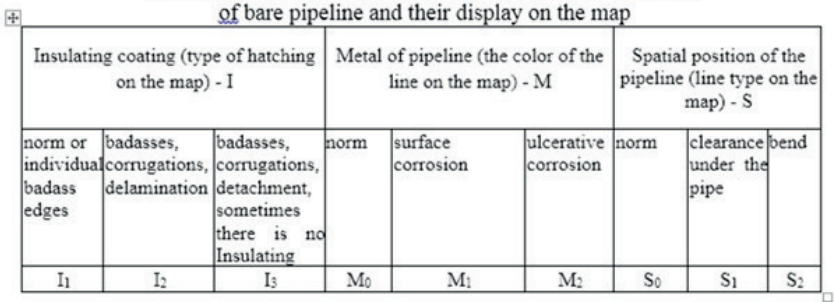

Type of defect View of the gas pipeline line on the map

$\mathrm{I}_{1} \mathrm{M}_{0} \mathrm{~S}_{0}$

$\mathrm{I}_{3} \mathrm{M}_{1} \mathrm{~S}_{0}$

$\mathrm{I}_{2} \mathrm{M}_{1} \mathrm{~S}_{2}$

$\mathrm{I}_{3} \mathrm{M}_{2} \mathrm{~S}_{3}$

Fig. 3. The fragment of the map of landforms 


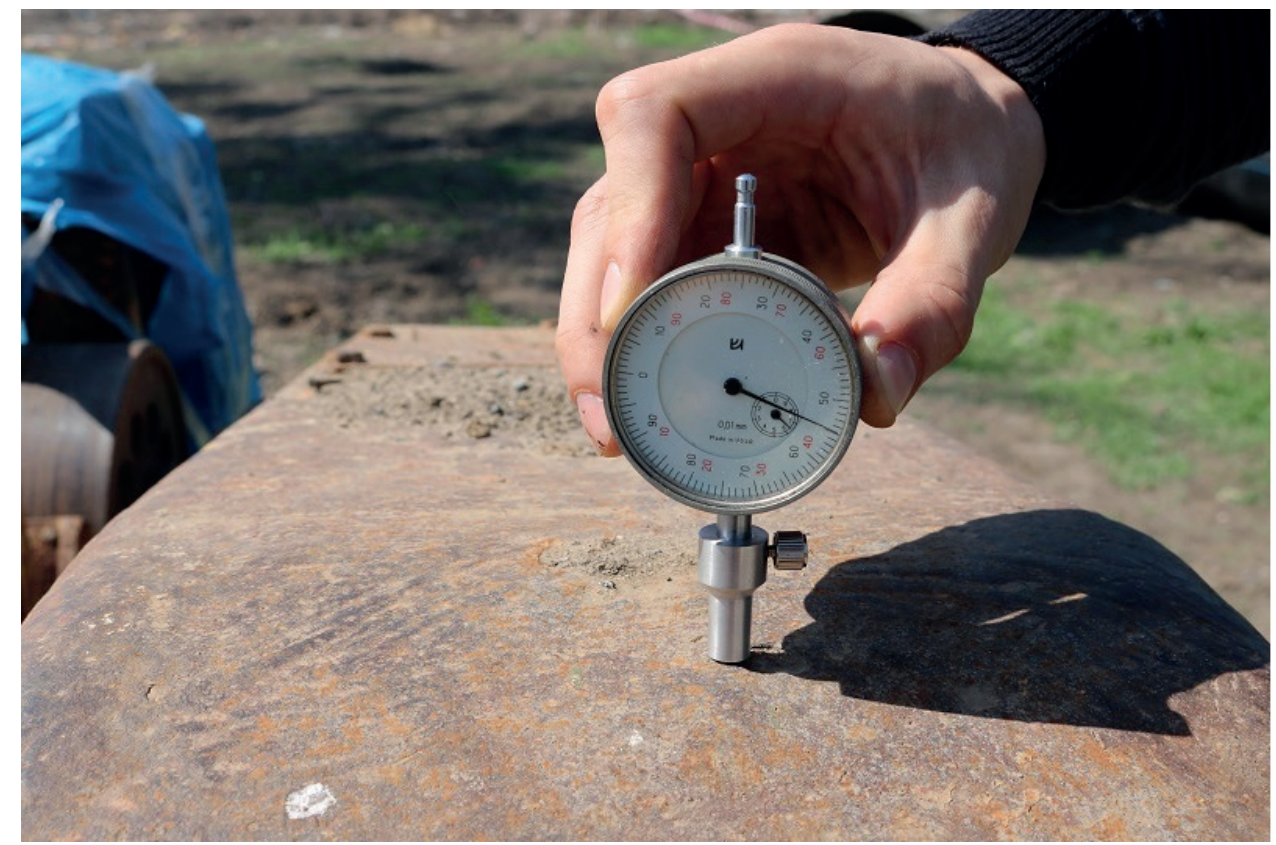

Fig. 4. The device for measuring the depth of corrosion pits (accuracy $0.01 \mathrm{~mm}$ )

reduction process in a pipeline micro galvanic couple, and pipelines interacting with the electric field of the Earth cause the appearance of macro galvanic couple. These macro galvanic couples arise due to differences in aeration conditions in soils along the pipeline. These resulting currents Evans called the currents of differential aeration (Evans 1962). In Russia (Mikhailovsky, Tomashov 1958) it was considered correct to speak not about the corrosiveness of certain soils but about the corrosiveness of the pipeline in combination with soils.

There is a close relationship between the value of Eh and the degree of soil aeration (oxygen access). In dry sections of the route with good oxygen access high values of Eh are observed and in low-water areas - low values. According to Nikitenko (Nikitenko 1965) relief and vegetation predetermine different soil moisture along the pipeline route and consequently indirectly control the aeration of the soil. Thus the fluctuation of Eh values occurs under the influence of the whole complex of natural components: permafrost conditions (seasonally thawed layer depth), soils (lithology), surface topography of tracts and vegetation.

\section{RESULTS AND DISCUSSION}

The results of determining the depth of pitting corrosion and physico-chemical characteristics of soils in the different landscape types of the territory of the gas field Medvezhye are presented in Table 2.

According to Table 2 we made an attempt to establish a statistical connection between the Eh and the depth of pitting corrosion in the metal of the pipeline. The connection between the depth of corrosion $(H)$ and the value of Eh can be approximated by the formula $H \approx-0.0014 E h+1.49$. In this case the correlation coefficient $R^{2}=-0.22$. For other indicators $(\mathrm{pH}$ and $\rho)$ the correlation with the depth of corrosion is even less. Thus this approach to assessing the corrosion hazard of cryogenic landscapes turned out to be unpromising.

After that we tried to use the data of the length of sections of the pipeline with pitting corrosion (Fig. 5) within different landscape types and to compare these data with the value of Eh and its standard deviation from the average

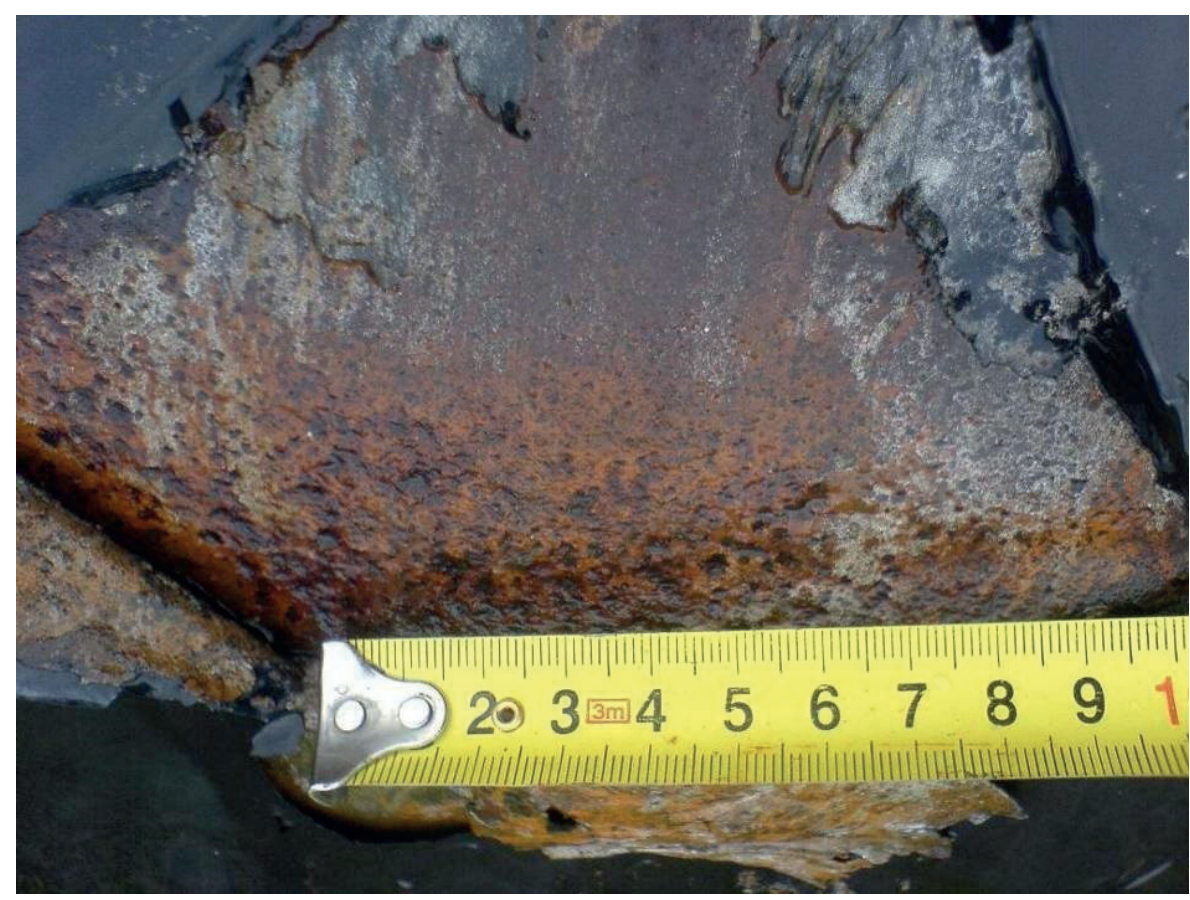

Fig. 5. Pitting corrosion of the metal of the gas pipeline 
Table 2. The main characteristics of soils in the different landscape types $(E h, p H, \rho)$ and the depth of pitting corrosion in the metal of gas pipelines of the inter field collector

\begin{tabular}{|c|c|c|c|c|c|c|c|c|c|c|c|}
\hline № & $\begin{array}{l}\text { Landscape } \\
\text { type }\end{array}$ & $E h, m V$ & $p H$ & $\rho, O m \cdot m$ & $\begin{array}{l}\text { The depth of } \\
\text { corrosion } \mathrm{H}, \mathrm{mm}\end{array}$ & № & $\begin{array}{l}\text { Landscape } \\
\text { type }\end{array}$ & $E h, m V$ & $p H$ & $\rho, O m \cdot m$ & $\begin{array}{l}\text { The depth of } \\
\text { corrosion } \mathrm{H}, \mathrm{mm}\end{array}$ \\
\hline 1 & \multirow{10}{*}{ Forest } & 319 & 5.3 & 4 & 2.0 & 31 & \multirow{8}{*}{ Peatland } & 309 & 3.9 & - & 1.0 \\
\hline 2 & & 239 & 6.4 & 12 & 0.5 & 32 & & 255 & 5.8 & 1 & 0.0 \\
\hline 3 & & 185 & 5.9 & 7 & 0.0 & 33 & & 44 & 5.0 & 61 & 2.0 \\
\hline 4 & & 246 & 6.2 & 11 & 1.0 & 34 & & 64 & 6.4 & 6 & 0.0 \\
\hline 5 & & 103 & 6.3 & 3 & 3.0 & 35 & & 56 & 6.1 & 5 & 0.1 \\
\hline 6 & & 152 & 5.8 & 14 & 0.0 & 36 & & 64 & 5.7 & 2 & 0.5 \\
\hline 7 & & 222 & 5.9 & 64 & 0.0 & 37 & & 64 & 5.8 & 3 & 2.0 \\
\hline 8 & & 209 & 5.8 & 49 & 0.1 & 38 & & 65 & 6.7 & 4 & 0.0 \\
\hline 9 & & 215 & 5.2 & 12 & 0.0 & 39 & \multirow{21}{*}{ Swamp } & 250 & 6.4 & 11 & 0.0 \\
\hline 10 & & 216 & 5.2 & 55 & 0.0 & 40 & & 371 & 3.8 & - & 1.0 \\
\hline 11 & \multirow{20}{*}{ Tundra } & 282 & 5.4 & 6 & 1.5 & 41 & & 330 & 4.6 & 2 & 1.0 \\
\hline 12 & & 72 & 5.4 & 9 & 0.0 & 42 & & 325 & 4.6 & 17 & 0.0 \\
\hline 13 & & 259 & 6.0 & 4 & 0.0 & 43 & & 236 & 6.4 & 12 & 0.5 \\
\hline 14 & & 287 & 5.4 & 3 & 0.0 & 44 & & 179 & 5.3 & 14 & 0.0 \\
\hline 15 & & 285 & 5.6 & 10 & 0.0 & 45 & & 168 & 5.4 & - & 0.5 \\
\hline 16 & & 287 & 5.2 & 12 & 0.0 & 46 & & 48 & 4.0 & - & 1.0 \\
\hline 17 & & 311 & 5.1 & 54 & 0.0 & 47 & & 88 & 6.0 & - & 2.0 \\
\hline 18 & & 173 & 6.2 & 15 & 0.0 & 48 & & 38 & 4.5 & 58 & 2.5 \\
\hline 19 & & 161 & 5.2 & 4 & 0.0 & 49 & & 210 & 5.7 & 13 & 0.0 \\
\hline 20 & & 230 & 5.8 & 16 & 1.5 & 50 & & 37 & 3.5 & 9 & 0.0 \\
\hline 21 & & 213 & 5.5 & 39 & 0.0 & 51 & & 136 & 5.3 & 75 & 0.1 \\
\hline 22 & & 166 & 5.7 & 27 & 0.0 & 52 & & 88 & 5.0 & - & 2.0 \\
\hline 23 & & 215 & 6.2 & - & 0.0 & 53 & & 69 & 4.0 & 9 & 3.0 \\
\hline 24 & & 209 & 5.5 & 19 & 0.0 & 54 & & 46 & 4.4 & 6 & 0.0 \\
\hline 25 & & 202 & 6.0 & - & 3.0 & 55 & & 72 & 5.8 & 2 & 0.0 \\
\hline 26 & & 97 & 5.2 & - & 1.0 & 56 & & 75 & 5.5 & - & 1.0 \\
\hline 27 & & 90 & 5.5 & 5 & 0.0 & 57 & & 81 & 5.3 & 14 & 0.0 \\
\hline 28 & & 104 & 5.4 & 14 & 0.0 & 58 & & 37 & 4.6 & - & 0.1 \\
\hline 29 & & 98 & 5.5 & 6 & 1.5 & 59 & & 50 & 3.3 & - & 2.0 \\
\hline 30 & & 116 & 5.3 & 3 & 0.5 & & & & - & & \\
\hline
\end{tabular}

Table 3. The average values of the redox potential $E h$, standard deviation of the potential $\Delta E h$ and the prevalence of areas with pitting corrosion of the pipeline in different types of landscape

\begin{tabular}{|c|c|c|c|c|c|c|}
\hline Landscape type & $\overline{E h} m V$ & $\Delta E h m V$ & $\begin{array}{c}\text { The number of } \\
\text { samples } \\
\text { (Table 2) }\end{array}$ & $\begin{array}{c}\text { The length of the } \\
\text { gas pipeline in this } \\
\text { landscape type }(L), k m\end{array}$ & $\begin{array}{c}\text { The length of sections } \\
\text { of the pipeline, with } \\
\text { pitting corrosion of } \\
\text { metal }\left(L_{k}\right), k m\end{array}$ & $\begin{array}{c}\text { The share of gas pipelines } \\
\text { with pitting corrosion } \\
\mathrm{N}=100\left(L_{k}, L\right), \%\end{array}$ \\
\hline Forest & 210.6 & 57 & 10 & 31.23 & 0.35 & 1.1 \\
\hline Tundra & 192.8 & 78 & 20 & 79.56 & 4.46 & 0.97 \\
\hline Peatland & 115.1 & 104 & 8 & 5.93 & 5.44 & 16.4 \\
\hline Swamp & 139.7 & 108 & 21 & 23.58 & & \\
\hline
\end{tabular}




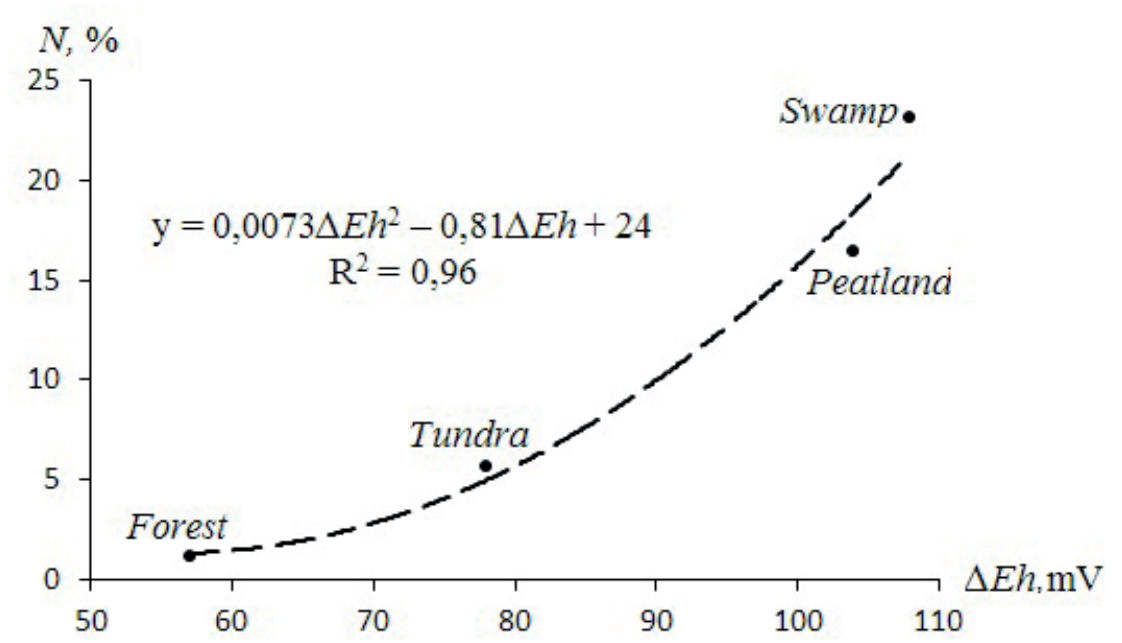

Fig. 6. The dependence of the proportion of sections of the gas pipeline with pitting corrosion $(\mathrm{N}, \%)$ on the standard deviation of the value of the redox potential $(\Delta \mathrm{Eh})$ in the different landscape types

value $(\triangle E h)$. The results of these studies that covered sections of the gas pipeline routes I and II with a total length of about $140 \mathrm{~km}$ are presented in Table 3.

The data of Table 3 make it possible to establish the corrosion hazard of different landscape types on a scale adequate to the dimensions of the structure itself, which was carried out for the first time in the practice of this kind of research. A noticeable connection is observed between $\triangle E h$ and $N$. Corrosion is the most active in the landscape types with frequent alternation of drained and flooded areas where $\Delta E h$ is high. It is observed in complex marshes and peat bogs where tuberous and ridged forms alternate with swampy marshes. The amplitude of Eh is closely related to the micro- and mesorelief. The low values of Eh are observed in the cavities on the periphery of peatlands and areas of peat-bog soils, and higher values are observed in drained areas. Often there are foci of corrosion between them and the size of the areas of them is related to the difference in the redox potentials of the irrigated and drained areas. So it can be assumed that the corrosiveness of soils in the landscapes of the permafrost zone is determined not by the absolute value of the redox potential Eh, but by the value of its standard deviation $\triangle E h$ from the average value (Velikotskij, Marakhtanov 2012; Velikotskij, Marakhtanov 2013). Thus, the larger the value of $\triangle E h$ within a landscape type the more corrosive this landscape type should be.

There is the close connection between $\Delta E h$ and the fraction of gas pipeline sections with pitting corrosion $N$ (Table 3) (correlation coefficient 0.96) that is approximated by the parabolic dependence shown in Fig. 6:

In conclusion we should add that in accordance with the theory of redox processes occurring in pipelines with the formation of corrosive pairs of differential aeration, oxidation (transition of iron to an ionic state) occurs at the anode and reduction (oxygen to hydroxyl and hydroxonium to free hydrogen) at the cathode. A discharge of electrons at the cathode activates corrosion at the anode. As a result of redox processes the value of Eh along the pipe undergoes sharp fluctuations: it is high at the cathode and low at the anode. The difference between the minimum values of the potentials of the anode and the maximum values of the potentials of the cathode characterizes electromotive force (EF) of a corrosion process, that is associated with the driving force of a chemical process - a change in the Gibbs energy. The Gibbs energy or the isobaric-isothermal potential $(-\Delta G)$ is the driving force of chemical reactions and electrochemical reactions calculated by the equation:

$$
-\triangle G=z F E
$$

Where $z$ is the number of electrons, $F$ is the Faraday number $=96500 \mathrm{C}, \mathrm{E}=\varphi \mathrm{K}-\varphi \mathrm{a}$ is the potential difference between the cathode and anode (B) (Shluger, Azhogin, Efimov, p. 33, 1981). In our case, the statistical potential difference of the anode and cathode is equal to twice the standard deviation $\triangle$ Eh from the average value. Using the above formula, it is possible to determine the thermal effect of the work or Gibbs energy of corrosion macro-systems of differential aeration of selected landscape types. For forest types of tracts: $z=2, F=96500 \mathrm{C}, E=2 \times 0.057 \mathrm{~B},-\triangle \mathrm{G}=22$ $\mathrm{kJ} / \mathrm{mol}$; for tundra tracts $-\Delta \mathrm{G}=30 \mathrm{~kJ} / \mathrm{mol}$; for peat tracts $-\Delta \mathrm{G}=40 \mathrm{~kJ} / \mathrm{mol}$; for marsh tracts $-\Delta \mathrm{G}=41.6 \mathrm{~kJ} / \mathrm{mol}$.

Therefore, the higher the potential difference (in terms of $\triangle E h$ ), the Gibbs energy and the heat generation, the more intense is the corrosion process in corrosive macropairs.

\section{CONCLUSIONS}

1. The amplitude of fluctuations in the value of the redox potential (RP) of soils ( $\triangle E h)$ is an effective indicator of the corrosion activity of tracts in the cryolithozone.

2. The standard deviation of the RP $(\triangle E h)$ is an indicator of the magnitude of the electromotive force of the corrosion process in macrogalvanic vapors arising on pipelines during differential aeration of soils.

3. By the value of $\triangle E h$ the maximum activity of corrosion is observed in swamps and peatlands (104-108 $\mathrm{mV}$ ) the average one in the tundra $(78 \mathrm{mV})$ and the smallest one in the forest tracts $(57 \mathrm{mV})$.

4. The experience in assessing the corrosiveness of permafrost landscapes obtained by studying the corrosion state of steel interfield collectors of the gas field Medvezhye can be applied in the permafrost zone of Western Siberia and the European part of Russia. 


\section{REFERENCES}

Velikotskij M.A. (2004). The impact of technogenic loads on landscapes in the permafrost zone. Geography, society, environment, (4). Natural and anthropogenic processes and environmental risk. Moscow: Moscow Publishing House. University, Faculty of Geography. $99-112$. (in Russian).

Velikotskij M.A. (2010). Corrosive activity of soils in different natural zones. Vestnik Mosk. Univ., Ser.5, 1, 21-27. (in Russian).

Velikotskij M.A. (2016). Assessment of the corrosiveness of landscapes to steel pipelines using the gas field Medvezhye as example. // Proceed. of the V Conf. of Geocryologists of Russia, Moscow State University, June 14-17, 2016, (1), 176-181. (in Russian).

Velikotskij M.A. (2018). Climate-hydrogeochemical zoning of the European part of Russia and Western Siberia and assessment of the danger of underground corrosion of gas transmission systems. Pipeline transport (theory and practice), 1(65), 43-49. (in Russian).

Velikotskij M.A., Egurtsov S.A. (2008). On the problem of assessing the corrosion activity of permafrost dispersed soils. The cryosphere of the Earth, 12(3), 50-57. (in Russian).

Velikotskij M.A., Marakhtanov V.P. (2012). Assessment of the corrosion activity of cryolithozone landscapes. // Proceed. of the Tenth Intern. Conf. on Permafrost (TICOP): Resources and risks of permafrost regions in a changing world, (3), Articles in Russian. Ed. V.P. Melnikova. Tyumen, Russia: Pechatnik, 75-79. (in Russian).

Velikotskij M.A., Marakhtanov V.P. (2013). New criteria for identifying the corrosion hazard of northern landscapes for gas pipelines. Gas Industry, 02/686, Moscow, 55-58. (in Russian).

Velikotskij M.A., Marakhtanov V.P. (2017). Corrosion activity of cryolithozone landscapes with respect to steel pipelines. Landscape science: theory, methods, landscape-ecological support and sustainability of development. // Proceed. of the XII Intern. Landscape Conf. Tyumen-Tobolsk, August 22-25, 2017. Tyumen State. Univ., Tyumen, (2), 444-447. (in Russian).

Kolotovsky A.N., Egurtsov S.A., Skrynnik T.V., Danilov O.A., Korolev A.E., Velikotskij M.A. (2015). Zoning of the territory according to the degree of dynamic hazard of natural processes. Recommendations for Gazprom. Moscow: Gazprom. Gazprom 2-2-791-2014. (in Russian).

Landscapes of the permafrost zone of the West Siberian gas province. (1983). Melnikov E.S., Weisman L.I., Moskalenko N.G., et al. Novosibirsk. (in Russian).

Marakhtanov V.P., Velikotskij M.A., Egurtsov S.A., Chigir V.G., Menshikov S.N., Polozov V.N. (2009). Diagnosing the technical condition of the interfield colltctor of the gas field Medvezhye (methodology and results). Transport and Underground Gas Storage (Scientific and Technical Collection), (3), Gazprom, 5-15. (in Russian).

Marakhtanov V.P., Velikotskij M.A. (2015). Optimization of the location of the designed trunk gas pipelines in the north of Western Siberia, taking into account landscape features. Pipeline transport: theory and practice, (1), 28-31.

Marakhtanov V.P., Velikotskij M.A., Egurtsov S.A. (2012). Assessment of the influence of landscape conditions on the technical condition of gas pipelines in the north. Oil and Gas Business, 4, 81-92. (in Russian).

Marakhtanov V.P., Velikotskij M.A., Chigir V.G. et al. (2011). Techno-ecological analysis of gas transmission systems of the gas field Medvezhye. // Proceed. of the Fourth Conf. of Russian Geocryologists, (3), Moscow: Publishing house of Moscow University, 49-55. (in Russian).

GOST 9.602-89. (1989). Underground facilities. Moscow: Publishing house of standards. (in Russian).

Mingalev E.P. (1978). Corrosion of underground pipelines in the peat soils of Western Siberia. Moscow: VNIIOENG. (in Russian).

Mikhailovsky Yu.N., Tomashov N.D. (1958). Method for determining the corrosion properties of soils. Theory and practice of corrosion protection of underground structures. Moscow: Publishing House of the Academy of Sciences of the USSR, 209-223. (in Russian).

Nikitenko E.A. (1965). Dependence of corrosion of a steel gas pipeline on changes in soil conditions along the route. Protection of metals, (1), 1, 91-98. (in Russian).

Srizhevsky I.V. (1986). Underground corrosion and protection methods. Moscow: Metallurgy. (in Russian).

Shluger M.A., Azhogin F.F., Efimov E.V. (1981). The corrosion and the metal protection. Moscow. (in Russian).

Evans Yu.R. (1962). Corrosion and oxidation of metals. Moscow: Mashgiz. (in Russian).

Velikotskij M.A. (2015). The identifying of dangerous of corrosion of gas pipelines in permafrost regions. International Geographical Union Regional Conference GEOGRAPHY Russia Local Organising Committee. Lomonosov Moscow State University.

Velikotskij M.A., Marakhtanov V.P. (2012). Assessment of the Corrosiveness of Permafrost Landscapes / Melnikov P.I. (ed.). // Proceed. of the Tenth Intern. Conf. on Permafrost, (2), Translations of Russian Contributions. Co-edited by D.S. Drozdov and V.E. Romanovsky. The Northern Publisher, Salekhard, Russia, 509-512. 